Yv. H. Ylyev,

Candidate of Philology,

Associate Professor,

Plovdiv University Lyuben Karavelov, Branch Kardzali,

26 Belomorski Blvd., 26, 6600, Bulgaria,

tel : +359886787696 ,

ivan_iliev20002000@yahoo.com

\title{
ON THE ORIGIN OF THE INHABITANTS OF KAYRACLIA AND SOME OTHER BULGARIANS IN UKRAINE
}

\begin{abstract}
Summary
This article is a continuation of a previous research by the same author (On the Origin of the Population of the Villages of Loshtonovka and Suvorovo in Ukrainian Bessarabia), in which an attempt to show that the population of the Bessarabian villages of Loshtinovka and Suvorovo originates from the village of Malomirovo in South-Eastern Bulgaria was made. The phonetic, morphological, syntactic, and lexical proofs that were used in the previous article, are extended here by the data from the Atlas of the Bulgarian dialects in USSR and personal observations. They not only confirm that the previous observations of the author were correct but also show which other villages in Ukraine have dialects similar to the macrodialect of Malomirovo, Suvorovo and Loshtinovka, as well as where their inhabitants could originate from.
\end{abstract}

Key words: Bulgarian language, Bulgarian dialectology, Bulgarian dialects in Bessarabia, Atlas of the Bulgarian dialects in USSR.

Надійшла до редакиії 31.08.2019 p.

УДК 811.161.1'373.227:821.161.1-1 Есенин /УДК 801/

DOI: https://doi.org/10.18524/2413-0613.2019.23.183132

Jolanta Kur-Kononowicz (https://orcid.org/0000-0001-9107-4790)

dr nauk humanistycznych w zakresie językoznawstwa,

adiunkt Uniwersytetu Rzeszowskiego, Instytut Filologii Rosyjskiej,

Al. mjr. W. Kopisto 2b, 35-315 Rzeszów, Polska,

tel.: +48(17)8721220,

jolanta_malgorzata@wp.pl

\section{Z ROZWAŻAŃ NAD SYMBOLIKĄ ZIÓŁ W IDIOSTYLU SERGIUSZA JESIENINA}

Celem artykułu jest lingwistyczna analiza symboliki ziół w idiostylu Sergiusza Jesienina. Materiał badawczy stanowią oryginalne wiersze rosyjskiego poety. Metoda analizy semantycznej łączy się w artykule $\mathrm{z}$ metodą lingwokulturologicznego opisu materiału językowego w polach semantycznych. Zioła rozumiane są jako subpole „rośliny” w semantycznym polu znaczeniowym „przyroda”. Przedmiotem opisu stały się m.in. nazwy: ковыль (ostnica), куnьрь (trybula), крапива, мак. W artykule omówiony został problem archetypów symboli. Opisowi podlegają stylistyczne środki językowe pomocne w zobrazowaniu poszczególnych symboli ziół w idiostylu Jesienina. Wyróżnione zostały $\mathrm{m}$. in. symbole: metaforyczne, metonimiczne, porównania itp. Analiza pokazała specyfikę i wyjątkowość symboliki ziół w utworach poetyckich Jesienina, wynikającą między innymi z ogromnej fascynacji poety przyrodą.

Slowa kluczowe: poezja, semantyka, symbolika, idiostyl, metaforyka.

Wprowadzenie. Znacznym utrudnieniem w badaniach symboliki jest wieloznaczność samego terminu symbol [6, s. 325]. W pracy symbol rozumiany jest szeroko i oznacza przedmioty, pojęcia, wyobrażenia, przeżycia kojarzące się z innym 
przedmiotem, pojęciem [Kop, s. 8]. Bez wątpienia zgodzić się trzeba ze stwierdzeniem, że analizie symboliki towarzyszyć musi dokładna interpretacja [5, s. 66]. W artykule analizujemy semantyczne zależności z punktu widzenia odpowiedniości nieprzenośnego i przenośnego (metaforycznego) znaczenia W symbolu (uzupełnione interpretacją filologiczną) [13, s. 126].

Zioła w kulturze. Zioła były znane ze swych właściwości leczniczych już w starożytności. Znalazły szerokie zastosowanie w medycynie ludowej. Aby uzyskać najskuteczniejszą moc ziół, należało je zbierać samotnie lub w towarzystwie, ale koniecznie do wschodu słońca. Najbardziej wartościowe, w stu procentach skuteczne w działaniu uzdrawiającym czy też magicznym były rośliny zielne zbierane w noc Iwana Kupały [СД, т. IV, c. 409].

$\mathrm{W}$ tekstach folklorystycznych (tj. legendach, podaniach, zagadkach, pieśniach) rośliny, w szczególności lecznicze, nabierają od samego początku znaczenia symbolicznego opartego na dostrzeganiu podobieństw pomiędzy światem przyrody i światem ludzi. Porównanie człowieka i rośliny jest charakterystyczne dla liryki ludowej [СД, т. IV, с. 411]. W artykule zajmiemy się analizą roślin, które mogą być surowcem zielarskim, mają właściwości lecznicze, przyprawowe, a czasami też trujące.

Symbolika ziól w idiostylu Jesienina. Przedmiotem analizy będzie symbolika następujących roślin leczniczych pojawiających się w twórczości poetyckiej Sergiusza Jesienina: ковыль (ostnica) (3), крапива (3), мак (3), купь́рь (trybula) (2). Ze względu na ich właściwości lecznicze zwrócono uwagę również na takie rośliny jak: клен, прутник (ива, ветла, верба) (wierzba). W zebranym materiale poetyckim trzykrotnie pojawiły się zioła: ковыль, крапива, мак.

Ковыль (ostnica). Roślina znana pod nazwą ковыль, ostnica piórkowata (pierzasta, Jana) od dawna stosowana była do leczenia tarczycy oraz paraliżu, a dzisiaj traktuje się ją głównie jako roślinę ozdobną. Rośnie na słonecznych i suchych zboczach. W Polsce jest zaliczana do ginącej roślinności stepowej i znajduje się pod 
ścisłą ochroną. Roślina lubi słone podłoża. Tylko wiosną jest zielona, latem wysycha [3, s. 574]. [1] Дрогнули листочки, закачались клены,

С золотистых веток полетела пыль...

Зашумели ветры, охнул лес зеленый,

Зашептался с эхом высохший ковыль... (Буря, 1914-1915) (Drgnęły listki, zakołysaly się klony, / Ze złotawych gałązek obleciał kurz... / Zaszumiały wiatry, jęknął las zielony, / Rozszeptala się z echem zeschnięta ostnica... Wszystkie polskie wersje tekstów Jesienina zawarte w artykule stanowią przekłady filologiczne sporządzone przez autorkę).

Fragment jest poetyckim opisem natury przed nastaniem niepogody. Stanowi opis burzy w letni dzień, która jawi się jako dar dla umęczonych brakiem wody roślin. Deszcz dla roślin jest ratunkiem od śmierci, warunkiem życia. Realizm zjawiska podkreśla właściwa kolorystyka i dźwięk. Zieleń, jako symbol nadziei, zostaje wyeksponowana poprzez wyraźną opozycję kolorystyczną do blado-żółtej z powodu suszy rośliny. Początkowo słychać drżenie liści, potem szum klonów, a na końcu - całego lasu. Пыль symbolizuje upływ czasu, a złote gałązki odwołują się do symboliki bogactwa (materialnego, ale przede wszystkim - duchowego). Chrześcijańska interpretacja znaczenia złota związana jest $\mathrm{z}$ chwałą, radością, miłością, a złota gałąź to nieśmiertelność [Kop, s. 496]. W tym fragmencie opisowi podlega początek burzy, która symbolizuje niepokój, przestrach przed mającymi nastąpić zmianami w przyrodzie. Są to zmiany nie tylko niszczące, ale i długo wyczekiwane, bo burza przynosi deszcz, a woda to życie, odrodzenie [Kop, s. 477478]. Moc natury zaczyna się objawiać stopniowo, od drgających liści. Kołyszące się na wietrze klony wywołują zaniepokojenie, chociażby dlatego, że drzewa te Słowianie wschodni uważali za szczęśliwe, a nawet święte. Sadzono je w pobliżu domu, przypisując im uzdrawiającą moc. Gałązki wykorzystywano w obrzędach Świętej Trójcy, Zielonych Świątek, Bożego Ciała czy podczas wschodniosłowiańskiego święta świętego Iwana. Święcone gałązki klonu mocowano nad drzwiami wejściowymi, w kątach izby, na oknach, pod łóżkiem, pod stołem, przyozdabiano nimi ikony [CД, т. II, c. 508].

Czas trwania niekorzystnego stanu pogodowego (tutaj: suszy), prowadzącego do śmierci roślin, doskonale obrazuje metafora peryfrastyczna ( $\mathrm{W}$ artykule zastosowano podział metafor polskiego teoretyka literatury, H. Markiewicza, na metafory: peryfrastyczne (opisowe), 
ewokacyjne (skojarzeniowe), konfrontacyjne. Por. H. Markiewicz. Uwagi o semantyce i budowie metafory // Studia o metaforze II. Z dziejów form artystycznych w literaturze polskiej / Pod red. M. Głowińskiego i A. Okopień-Sławińskiej. Wrocław: Ossolineum. PAN, 1983. S. 43-59.) Зашептался с эхом высохиий ковьлль..., przede wszystkim dzięki trafnemu sąsiedztwu czasownika зашептался (niechcący był za długo, zadomowił się w ciszy krajobrazu, pejzażu lub też zaczął wykonywać jakieś ruchy - zwiastujące zmiany - zamiast wypalać się na słońcu w bezruchu) i rzeczownika echo, mogącego oznaczać interwencję w panujący ład, hałas (por. gwarowe określenia echa: поголос, гул, отголосок). Wśród rosyjskich wierzeń ludowych znane jest to, które pozwala przewidywać pogodę na podstawie głośności echa. Głuche echo zwiastowało złą pogodę, a więc np. zbliżającą się burzę [СД, т. V, с. 598]. Dzięki animizacji (дрогнули листочки, закачались клены, охнул лес зеленыци, зашептался с эхом) оpis burzy zyskuje na znaczeniu przenośnym. Las może symbolizować ziemię, co utwierdza w trójwymiarowości obrazu poetyckiego [Kop, s. 189].

W analizowanym fragmencie wiersza roślina lecznicza ковыль symbolizuje: niepokój, strach przed nagłymi zmianami; nadzieję (percepcja świata); lato (pory roku); suszę, szum (zjawiska przyrody); śmierć (zdarzenia losowe); człowieka. Klon natomiast symbolizuje: niepokój, bezsilność; świętość, szczęście (percepcja świata). Archetyp symbolu (metaforycznego) ostnicy należy uznać za ogólnokulturowy.

\section{[2] О сторона ковыльной пущи,}

Ты сердцу ровностью близка,

Но и в твоей таится гуще

Солончаковая тоска. (За темной градью перелесиц, 1915-1916, 95) (Solnisko 'obszar bagienny, o znacznym zasoleniu wód' [O, c. 664]; O kraju ostnicowej puszczy, / Jesteś sercu równością bliski, / Ale w twoim kryje się gąszczu / Solniskowy smutek)

W peryfrastycznej metaforze $О$ сторона ковьльной пущи... ковыль kojarzy się ze stronami rodzinnymi, małą ojczyzną, a jednocześnie ze spokojem - za sprawą równości, tj. równinnego krajobrazu. Równiny symbolizować mogą ludzi zrównoważonych, opanowanych, rozumiejących przyrodę (sens istnienia). Krzątanina, niepokój, pośpiech miasta staje się widoczną opozycją do spokoju, ciszy, stałości, równowagi wsi. Puszcza symbolizuje miejsce schronienia, także ukrycia smutku - solniskowego, czyli pochodzącego ze słonego podłoża (gleby). Poprzez 
hiperbolizację smutku (sól odnosi się również do znaczenia smutku) pojawia się poetycki obraz smutku niepotrzebnego, destrukcyjnego $\mathrm{z}$ jednej strony oraz „zapobiegającego zepsuciu”, obdarowującego pokorą z drugiej strony [Kop, s. 399]. Łąka traw, przeobrażając się w puszczę, pośrednio przywołuje w pamięci symbol ziemi, podłoża (gleby) [Kop, s. 190] oraz życia - jak się dalej okazuje - w pokorze.

W powyższym cytacie pojawiają się następujące symbole ostnicy: mała ojczyzna, puszcza (las), ziemia (miejsce); zrównoważenie, spokój; smutek; pokora (percepcja świata); wielość, mnogość, zbiorowość (liczba, wielkość). Poeta nie zatrzymuje się dłużej na symbolice właściwości uzdrawiających ostnicy (poza mocą uzdrawiania ludzkiego charakteru), jak gdyby nie była ona dominująca w postrzeganiu rośliny. Archetyp symbolu (metonimicznego) ostnicy należy do ogólnokulturowych.

[3] Уж не сказ ли в прутнике

Жисть твоя и быль,

\section{Что под вечер путнику}

Нашептал ковыль? (Край ты мой заброшенный, 1914, Е 90) (Сказ 'rodzaj ludowopoetyckiego podania, legendy, baśni, narracji (prowadzonej przez gawędziarza, narratora, opowiadającego); uważany za gatunek ustnej twórczości ludowej [O, c. 640]; Прутник 'krzew wiklinowy', wyraz gwarowy: syberyjski, nowogrodzki [CPHГ, т. XXXIII, c. 68]; Czy to nie baśń w wiklinie / O nieprawdzie i prawdzie, / Wieczorową porą podróżnemu / Wyszeptala ostnica?)

We fragmencie przedstawiono hiperbolizację końca, śmierci rodzinnej wioski spowodowaną masowymi wyjazdami młodych ludzi za chlebem (w poszukiwaniu pracy, nauki itd.). Głębszy sens kryje się w przenośnym znaczeniu (stającym się symbolem) pożegnania $\mathrm{z}$ domem rodzinnym, rodzinnymi stronami i umiejscowieniem tego miejsca w głębokiej pamięci. Nakładają się na siebie końce: życia wsi - dnia (wieczór) - opowieści ludowej. Zarośla wiklinowe (iwowe) symbolizować mogą niedostępność, ukrycie, zmyślenie, nieprawdę, a sama wierzba (iwa) - smutek, tęsknotę, śmierć [Kop, s. 459-460]. Ostnica symbolizuje tutaj: strony rodzinne (miejsce); bajarza (osoba); ciszę, spokój; mrzonkę, wymysł; wspomnienie dzieciństwa (percepcja świata); śmierć wioski rodzinnej (zdarzenia losowe). Roślina о właściwościach leczniczych - ива, symbolizuje: niedostępność, ukrycie, nieprawdę (percepcja świata); smutek, tęsknotę (uczucia); śmierć (zdarzenia losowe). Archetyp symbolu (metaforycznego) ostnicy jest ludowy. 
Obraz ostnicy w idiostylu Jesienina. Ostnica w poetyckiej twórczości Jesienina pojawiła się trójkrotnie. Poeta postrzega roślinę poprzez jej wyjątkowe zdolności do wysychania w środku lata, a także - symbiozę tej rośliny stepowej ze słonym podłożem. Widzi ją jako roślinę porastającą rozległe obszary stepowe, tworzącą zarośla i mającą właściwości narracyjne, uaktywniające się pod wpływem częstych wiatrów stepowych. Trzeba również podkreślić, że ковыль zawsze jest utożsamiana z miejscem dzieciństwa i wczesnej młodości, czyli z rodzinną wsią.

Крапива (pokrzywa). Równie ważny dla poety, sądząc chociażby po częstotliwości występowania w utworach poetyckich, jest pospolity chwast i roślina lecznicza - pokrzywa. Pokrzywa w kulturze słowiańskiej od początku traktowana była jak amulet, talizman chroniący od wszelakich nieszczęść. Uważano, że to pospolite zioło powstało na skutek przeistoczenia się $\mathrm{w}$ nią przeklętych albo grzesznych ludzi lub też twierdzono, że roślina wyrosła na miejscu ich kaźni [СД, т. II, c. 644]. Etymologicznie nazwa pokrzywa odwołuje do czasowników palić, kluć, piec, parzyć, tj. 'kłuć' ze względu na włoski parzące pokrywające łodygę i liście rośliny [СД, т. II, c. 643].

[4] Улыбнулись сонные березки,

Растрепали шелковые косы.

\section{(...) У плетня заросшая крапива}

\section{Обрядилась ярким перламутром}

И, качаясь, шепчет шаловливо:

„С добрым утром!” (С добрым утром!, 1914) (Uśmiechnęły się senne brzózki, / Roztrzepały jedwabne warkocze. / (...) Przy płocie zarośnięta pokrzywa / Wystroiła się jaskrawą masą perłową / I, kołysząc się, szepcze figlarnie: „Dzień dobry!”)

Poetyckiemu opisowi podlega świt, a właściwie chwila oddzielająca noc od dnia. Przepiękny obraz powoli budzącej się z nocnego snu przyrody przepełniony jest nieczęsto odczuwaną i obserwowaną radością i spokojem. Pokrzywa, która we fragmencie jest zarośnięta, na krótko przypomina o negatywnym znaczeniu ubóstwa, spustoszenia, ruiny, upadku, pustki [СД, т. II, c. 646]. Dominującym symbolem staje się jednak radość, bogactwo, piękno ze względu na przywołanie masy perłowej, w którą wystroiła się roślina dzięki pierwszym promieniom słonecznym (metafora peryfrastyczno-ewokacyjna $У$ плетня заросшая крапива / Обрядилась ярким 
перламутром) [Kop, s. 307]. Wkładając w usta ożywionej pokrzywy słowa na dzień dobry, poeta hiperbolizuje radość. Dzięki zabiegowi animizacji powszechnie spotykany, znany przede wszystkim z parzących właściwości chwast postrzegany jest jako kobieta, która z kłótliwej, złośliwej i butnej zamienia się w zabawną, dowcipną kokietkę (И, качаясь, шепчет шаловливо).

U Jesienina pokrzywa przy płocie symbolizuje przede wszystkim rodzinną wieś, czyli powszedniość, zwyczajność występującą w opozycji do wysokiego nieba z ciepłym, jasnym słońcem, które wprowadza symbolikę wzniosłości. Ziemia jest obdarowywana odgórnie dobrem płynącym z nieba. Pokrzywa przedstawiona została dwuaspektowo dzięki opozycji, mogącej utwierdzać w przekonaniu, że jednoznaczność w opisywanej przez poetę rzeczywistości jest tylko iluzją. Domeną ówczesnego świata jest dwubiegunowość, niejednoznaczność. Pokrzywa symbolizuje w analizowanym fragmencie: rodzinną wioskę (miejsce); ubóstwo, spustoszenie, ruinę i piękno, radość, bogactwo; powszedniość, zwyczajność i wyjątkowość; niejednoznaczność (percepcja świata); dziewczynę kłótliwą i kokietkę (człowiek). Archetyp symbolu (metonimicznego) pokrzywy jest ogólnokulturowy, indywidualnoautorski.

[5] За горами, за желтыми долами

Протянулась тропа деревень.

Вижу лес и вечернее полымя,

И обвитый крапивой плетень.

Там с утра над церковными главами

Голубеет небесный песок,

И звенит придорожными травами

От озер водяной ветерок. (За горами, за желтыли долами, 1916) (Za górami, za żółtymi dolinami (za lasami) / Rozciągnęła się ścieżka wiosek. / Widzę las i wieczorny płomień, / I otulony pokrzywą płot. / Tam od rana nad cerkiewnymi kopułami / Błękitnieje niebiański piasek, / I dzwoni przydrożnymi trawami / Od jezior wodny wiaterek.)

W poetyckim obrazie pojawił się opozycyjnie ujęty opis krajobrazu, z górami i dolinami - co pozwala przenieść czytelnika w inny wymiar rzeczywistości. Cały wiersz spaja przenikanie się świata ziemskiego z niebiańskim, ludzkiego z Boskim. Góry symbolizować mogą stałość, drogę do nieba, raju, ale też samotność, wzniosłe myśli oraz sferę sakralną $\mathrm{z}$ racji bliskości nieba [Kop, s. 100-101]. Poetycki 
krajobraz poeta odkrywa stopniowo, poczynając od opisu najbardziej widocznych i zarazem najważniejszych symboli i kończąc na opisie mniej widocznych, ukrytych dla wzroku elementów, jak np. płot porośnięty pokrzywą.

Opis zbudowany jest na zasadzie opozycji - obok góry pojawia się dolina, która w tym wypadku w niewielkim stopniu zwraca uwagę na utratę górnolotności myśli, głównie za sprawą barwnej charakterystyki [Kop, s. 68]. Żółcień doliny (3a желтыли долами) nie pozwala zapomnieć o jasności, świetle, świętości, a także będąc barwą lata i jesieni (dojrzałe kłosy i opadające liście) - uaktywniać może symbolikę ciągłości życia, zmiany jego formy [Kop, s. 506]. Następnie dzięki metaforze ewokacyjnej Протянулась тропа деревень pojawia się symbolika drogi, a właściwie dróżki, ścieżki symbolizującej podróż, wędrówkę utożsamianą z drogą życia, poszukiwaniem prawdy, celów duchowych, istoty życia [Kop, s. 331]. Ukazana została znikomość życia mieszkańców wioski w odniesieniu do ogromu kosmosu (co nie pomniejsza jej wartości, tylko umiejscawia w Boskim wymiarze świata, przestrzeni). Występuje tutaj alegoria podróży jako odpowiednika ludzkiego życia. W dalszej kolejności pojawia się las wprowadzający symbolikę ziemi, pustelni [Kop, s. 189]. Wieczorny płomień przypomina o życiu duchowym, radości wewnętrznej; może również odsyłać do myśli o zbawieniu, szczęściu [Kop, s. 415416]. Przymiotnik wieczorny wzbogaca przedstawiony obraz poetycki o symbolikę końca - dnia, życia, która zyskuje pozytywny wydźwięk dzięki światłu płomienia.

Potem widzimy płot porośnięty pokrzywą. Płot, podobnie jak góra, to również przeszkoda - ta ziemska. Ponownie poeta umiejscawia życie ludzkie w przestrzeni kosmicznej. Pojawia się pokrzywa, hiperbolizująca przeszkody [СД, т. II, c. 643] i odsyłająca do pamięci o rodzinnej wsi, miejscu narodzin i dzieciństwa. Metafora peryfrastyczna И обвитый крапивой плетень kojarzy się czytelnikowi ze znaną wśród ludu od dawna negatywną symboliką pokrzywy - zwiastującą z powodu jej nadmiaru - ubóstwo, spustoszenie, ruinę, upadek, pustkę [CД, т. II, c. 646].

Pokrzywa symbolizuje tutaj: przeszkodę (rzecz); rodzinną wieś, miejsce narodzin i dzieciństwa (miejsce); ubóstwo, spustoszenie, ruinę, upadek (percepcja świata). Archetyp symbolu (metaforycznego) pokrzywy jest ludowy. 


\section{[6] В том краю, где желтая крапива}

\section{И сухой плетень,}

\section{Приютились к вербам сиротливо}

Избы деревень. (В том краю, где желтая крапива, 1915, E 96) (W tamtym kraju, gdzie żólta pokrzywa / I suchy płot, / Przytulily się do wierzb sieroco / Chaty wiosek.)

W metaforze peryfrastycznej В том краю, где желтая крапива / И сухой плетень рojawia się poetycki obraz żółtej pokrzywy zawierający nietypową symbolikę żółcienia - susza, brak życia, śmierć (rośliny). Jest to symbol autorski, indywidualny utworzony przez poetę. Pokrzywa symbolizuje zapewne ubóstwo, opustoszenie i dodatkowo - za pośrednictwem przymiotnika żólta - ogromny smutek, a nawet śmierć. Brak nadziei pośrednio może wiązać się $\mathrm{z}$ brakiem wody warunkującej życie. Do hiperbolizacji suszy, śmierci przyczynia się metafora ewokacyjna сухой плетень. Płot, który nabiera znaczenia granicy oddzielającej prywatność, intymność od ogółu jest zniszczony, wysechł, pomimo że w zasadzie jako rzecz martwa nie wykazuje symptomów życia.

Poeta opisuje opuszczone domostwa, używając kolejnej metafory peryfrastycznej, opisowej, z której wynika, że wierzby - mogące symbolizować bezdomność [Kop, s. 459] - przejmują opiekę nad osieroconymi chłopskimi chatami. Pokrzywa symbolizuje tutaj: ubóstwo, opustoszenie; smutek (percepcja świata); suszę, brak życia, śmierć (zdarzenia losowe). Wierzba symbolizuje: bezdomność (percepcja świata).Archetyp symbolu (metonimicznego) pokrzywy jest ludowy i ogólnokulturowy.

Obraz pokrzywy w idiostylu Jesienina. Pokrzywa w wierszach Jesienina występuje często ze względu na umiejscowienie jej w pamięci jako symbolu rodzinnej wioski. Крапива przywołuje skojarzenie ze zwyczajnością, pospolitością, normalnością życia, a nie - jak by można było przypuszczać - życiowymi przeszkodami. Wręcz przeciwnie, można odnieść wrażenie, że ta roślina powinna być nieodłącznym elementem krajobrazu. W promieniach słonecznych, mieniąc się w kolorach zieleni i bieli, upodabnia się nawet do perły. Ze względu na to, że pokrzywa zawsze umiejscawiana jest obok płotu, a więc przeszkody, bariery, może symbolizować pozytywną determinację w pokonywaniu przeciwności. 
Мак (mak). Mak zdaje się być niezwykle ważną rośliną w rzeczywistości postrzeganej przez Jesienina. Roślina ta była znana od dawna ze względu na jej nasiona dostarczające oleju. $\mathrm{Z}$ soku rośliny przygotowywano lekarstwo nasenne [CAP, т. IV, c. 18]. Mak od najdawniejszych czasów stosowany był w medycynie i magii. Makówki, poświęcone w kościele w dniu Matki Boskiej Zielnej, wkładano do kołysek płaczliwych dzieci [4, s. 109].

[7] Белая свитка и алый кушак,

Рву я по грядкам зардевшийся мак.

Громко звенит за селом хоровод,

Там она, там она песни поет.

(...) Белая свитка и алый кушак,

Рву я по грядкам зардевшийся мак.

Маком влюбленное сердце цветет,

Только не мне она песни поет. (Белая свитка и альй кушак, 1915) (Свитка или свита - rodzaj rosyjskiego, ukraińskiego lub białoruskiego stroju ludowego [БAC, c. 389]. W dialekcie orłowskim, kałużskim: koszula [СРНГ, т. XXXVI, с. 303]; Кушак - pas zwykle z szerokiego długiego kawałka materiału lub sznurka [БАС т. V, c. 1914; CAP, т. III, c. 1104]; Biała sukmana i purpurowy pas, / Rwę z rabatek zaczerwieniony mak. / Głośno dźwięczy za wsią korowód, / Tam ona, tam ona pieśni śpiewa / (...) Biała sukmana i purpurowy pas, / Rwę z rabatek zaczerwieniony mak. / Makiem zakochane serce kwitnie, / Tylko nie dla mnie ona pieśni śpiewa.)

Kolorowy orszak taneczny był nieodłącznym elementem zabaw i obrzędów ludowych; często wiązał się z obchodami jakiegoś święta ludowego. Tańczący korowód i zrywanie kwiatów maku wprowadza symbolikę trudności, przeszkód w zdobywaniu serca dziewczyny, chociażby dlatego, że korowody odbywały się po to, aby coś lub kogoś mającego ogromną moc przekonać do słuszności własnej prośby o deszcz, słońce, zdrowie, życie itp. Przekonywano, błagano śpiewami bóstwa, siły przyrody, Boga itp. Cytowany powyżej fragment wiersza, stylizowany na poezję ludową, pochodzi z wczesnego okresu twórczości Jesienina. W rosyjskich pieśniach weselnych dziewczynę porównuje się do kwiatów maku (красна как маков ц̧вет). Słowianie wschodni mieli w zwyczaju makiem czy też kwiatem maku nazywać oblubienicę [СД, т. III, c. 173]. Zrywane kwiaty maku symbolizują marzenia, myśli o ukochanej dziewczynie. Nie sposób pominąć jednak symboliki czerwieni, która może w tym przypadku odnosić się do cierpienia i ofiary młodzieńca nieszczęśliwie 
zakochanego [Kop, 55-56]. W opisie poetyckim czerwień ulega hiperbolizacji - jest obecna w kwiatach maku, kolorze paska oraz określa natężenie uczucia.

W metaforze peryfrastyczneј Маком влюбленное сердие ияветет pojawia się symbolika maku, którą należy powiązać z radością, słońcem (kwiat maku to lato) [Kop, s. 218], a także - z uwagi na czerwień - uaktywnia się symbol miłości [Kop, s. 57]. Z następującego dalej kontekstu (Только не мне она песни поет) wynika, że poeta odwołuje się do negatywnego znaczenia maku - zmartwienie, cierpienie z powodu braku wzajemności [Kop, s. 218]. Taka budowa wiersza, w której zostaje zestawiona na początku pozytywna, a na końcu negatywna symbolika, również ma swoje źródła w pieśniach ludowych. Mak w tym fragmencie utworu symbolizuje: ukochaną, oblubienicę (człowiek); czerwień (kolor); miłość; radość (uczucia); zmartwienie, cierpienie, ofiara (percepcja świata). Archetyp symbolu (metaforycznego) maku należy uznać za ludowy i ogólnokulturowy.

[8] Не гнетет немая млечность,

Не тревожит звездный страх.

Полюбил я мир и вечность,

Как родительский очаг.

Все в них благостно и свято,

Все тревожное светло.

\section{Плещет рдяный мак заката}

На озерное стекло. (Не напрасно дули ветры, 1917) (Рдяный - karminowy, krwawy, jasnoczerwony, purpurowy, karminowy. [O, c. 597]; Nie gniecie (dręczy) niema mleczność, / Nie trwoży gwiezdny strach. / Polubiłem pokój i wieczność, / Jak ognisko rodzinne. / Wszystko tam błogie i święte, / Wszystko trwożne jasne. / Pluska czerwony (krwawy) mak zmierzchu / Na szkło jeziora.)

Metafora ewokacyjna мак заката staje się czytelna, jeśli wziąć pod uwagę datę napisania wiersza, rok 1917 - po zakończeniu rewolucji lutowej w Rosji (o wybuchu rewolucji październikowej jeszcze nie myślano). Napięcie przedrewolucyjne ustało, nastąpiła ulga, spokój, oczekiwanie na rezultaty przełomowego wydarzenia. Spojrzenie w gwiazdy już nie dręczy. Mak zachodu słońca wnosi symboliczną semantykę piękna kończącego dzień (zachodu), a zarazem - optymizmu po zakończeniu przewrotu. Czerwień, a właściwie karmin czy też purpura, przywołuje pamięć o krwi, czyli niedawnych krwawych wydarzeniach, przypominając o pięknie poprzedzonym cierpieniem, ofiarą [Kop, s. 55 i s. 217]. W obrazie poetyckim 
czerwień przechodzi w niebieski odcień jeziora, uaktywniając semantykę spokoju i harmonii [Kop, s. 27]. Spokój hiperbolizuje metafora ewokacyjna озерное стекло oparta na podobieństwie koloru i blasku, sygnalizując nieruchomość, gładkość, równość powierzchni, a także - lekkość, jasność myśli. Poprzez odniesienie wód jeziora do szkła zniwelowane zostało skojarzenie wody z symboliką niestałości, zmienności czy niebezpieczeństwa (wynikającego z ogromnej głębokości) [Kop, s. 475]. Mak w tym fragmencie symbolizuje: optymizm, spokój, harmonię; ofiarę (percepcja świata); krew (rzeczy). Archetyp symbolu (metonimicznego) maku jest tutaj ogólnokulturowy.

Obraz maku w idiostylu Jesienina. Mak zwrócił uwagę poety przede wszystkim ze względu na rzucający się w oczy czerwony kolor kwiatów, ukazywanych w opozycji kolorystycznej np. do niebieskiej wody jeziora. Kwiaty rośliny pomagają wyrazić piękno zachodzącego słońca, siłę uczucia. Jesienin nie zapomina o usypiających właściwościach ziarenek makowych, których symbolikę wykorzystuje, aby zilustrować piękno ciszy, nocy. Kolejne znaczenie maku omówione zostanie poniżej, gdyż pojawia się razem $\mathrm{z}$ symboliką trybuli, występującej w wierszach Jesienina dwukrotnie.

Купырь (trybula). Kynыıрь jest rośliną zewnętrznie podobną do marchwi, a smakiem przypominającą seler, pietruszkę lub anyż. Wykorzystywany jest w gastronomii, przede wszystkim jako roślina sałatkowa. W medycynie ludowej stosowany jako lekarstwo w leczeniu nerek, dróg oddechowych, pęcherza moczowego. Należy do wczesnych roślin miododajnych, daje nektar. Wiosną słodkie łodyżki tej rośliny stanowią ulubiony przysmak dzieci w guberniach: penzeńskiej, tambowskiej, kałużskiej, nowosybirskiej, kurskiej, moskiewskiej, tulskiej [БАC, т. V, c. 1853; СРНГ, т. XVI, c. 105].

[9] Залюбуюсь, загляжусь ли

На девичью красоту,

\section{(...) В терем темный, в лес зеленый,}

На шелковы купыри,

Уведу тебя под склоны 
Вплоть до маковой зари. (Темна ноченька, не спится, 1911) (Терем - poddasze (dawniej: świetlica) w kształcie wieży, baszty, nadbudowane nad strychem w XVII-wiecznych pałacach carskich i dworach bojarskich; najwyższa kondygnacja przeznaczona wyłącznie dla kobiet (CAP, т. VI, c. 100). Owa nadbudówka zazwyczaj była wyodrębniona od reszty budynku wysokim malowniczym dachem. Mieszkały tam (zwykle w zamknięciu, pod kluczem) kobiety z carskich lub bojarskich rodzin [БAC, т. XV, c. 322]; Czy zachwycę się, czy zapatrzę się / Na dziewczęcą urodę, / (...) W terem ciemny, w las zielony, / Na jedwabne trybule, / Uprowadzę cię pod stoki (gór) / Aż do makowej zorzy.)

Kolorystyka w tym fragmencie zmienia się stopniowo - począwszy od czerni, ciemności nocy, poprzez zieleń lasu, aż po czerwień maku - wiodąc podmiot liryczny od niepewności, poprzez nadzieję na przyjemność, aż do realizacji marzeń. Metafora ewokacyjna На шелковы купьри przywodzi symbolikę posłania delikatnego, elastycznego, puszystego, a więc wygodnego oraz pośrednio być może odwołuje się do symboliki miodu i nektaru, ponieważ powszechnie trybula uznawana była za roślinę miododajną, z której pozyskuje się nektar (słodki smak łodygi) [БАC, т. V, c. 1853]. Wyżej wspomniane napoje wprowadzają do obrazu poetyckiego symbol pełnego szczęścia, najwyższego dobra ziemskiego i niebiańskiego, wiecznej szczęśliwości [Kop, s. 226]. Jednak posłanie, poprzez umiejscowienie w teremie, staje się symbolem odosobnienia, prywatności dwojga ludzi lub też przeznaczenia, ponieważ w takim pomieszczeniu dziewczyna czekała na oblubieńca pod kluczem, a także - symbolem piękna dziewczyny wynikającym również z faktu wysokiego urodzenia (każda wybranka jest jedyna jak carowa, księżna itp.). Las w dalszym kontekście przywodzi symbol wolności jako opozycji do zamknięcia w pomieszczeniu. Nieprzypadkowo pojawia się w tym fragmencie również mak stający się symbolem snu, marzenia [Kop, s. 217].

Kolejna roślina lecznicza pojawia się tutaj pośrednio poprzez porównanie kolorystyczne wieczornej zorzy do maku, a właściwie do makowego koloru symbolizującego dojrzałość, miłość, rozkosz [Kop, s. 217]. Kwiat maku poprzez intensywność barwy, oddziałującą na zmysły, odnosi się do znaczenia piękna, powabu. Przymiotnik makowy odwołuje się również do motywowanej wielością ziaren w makówce, ich mocą i usypiającymi właściwościami symboliki związanej ze snem, tj. ciszą i zapomnieniem, które daje nam odpoczynek nocny [Kop, s. 218; CAP, т. IV, c. 18]. Hiperbolizacji ulega ciemność, noc dzięki trafnemu zestawieniu 
до маковой зари, ponieważ zorza wieczorna również symbolizuje noc. Las przywołuje także znaczenie ciemności oraz ukrycia [Kop, s. 189], a poprzez zielony kolor daje też nadzieję na spełnienie najskrytszych marzeń. Góry, które pojawiły się w tym obrazie poetyckim, wnosić mogą podwójną symbolikę - $\mathrm{z}$ jednej strony wiecznej młodości, radosnego wypoczynku i z drugiej strony - znaczenie bariery oddzielającej ludzi od krainy czarów, marzeń [Kop, s. 101]. Trybula symbolizuje w powyższym fragmencie: wygodne posłanie (rzeczy); miód, nektar (napoje); pełne szczęście, wieczną szczęśliwość, najwyższe dobro ziemskie i niebiańskie; wyłączność, odosobnienie, prywatność, trafność wyboru; przeznaczenie, wolność (percepcja świata); sen, marzenie (stan), noc (czas, zjawisko przyrody); dziewczynę, oblubienicę (człowiek). Mak ujawnia symbolikę: ciszy, zapomnienia; piękna, powabu, dojrzałości (percepcja świata); miłości, rozkoszy (uczucia); ciemności, nocy (czas, zjawisko przyrody). Archetyp symbolu (metonimicznego) trybuli należy uznać za indywidualno-autorski.

[10] Матушка в Купальницу по лесу ходила,

Босая, с подтыками, по росе бродила.

\section{Травы ворожбиные ноги ей кололи,}

Плакала родимая в купырях от боли. (Матуика в Купальнииу по лесу ходила, 1912) (Matuchna w przeddzień święta Kupały po lesie chodziła, / Boso, potykając się, po rosie brodziła. / Zioła wróżebne nogi jej kłuły, / Płakała droga w trybulach z bólu.)

Nazwa kynырь pojawia się we fragmencie wiersza zawierającym opis obrzędu poprzedzającego święto Iwana Kupały (świętego Jana). Etymologia nazwy Купальница, 'święto obchodzone na terenie Słowiańszczyzny Wschodniej 23 czerwca', odnosi nazwę własną do czynności kąpieli, mającej w owym dniu właściwości uzdrawiające, oczyszczające ciało człowieka, obdzielające go zdolnościami nadprzyrodzonymi. Jest to słowiańskie święto pogańskie obchodzone na terenie guberni: kostromskiej, archangielskiej, pskowskiej, permskiej, wiackiej [CРНГ, т. XVI, c. 97]. Według wierzeń ludowych zioła zbierane w tym dniu miały największą moc, były najskuteczniejsze. Травы ворожбиные (zioła wróżebne) symbolizują: dużą wartość (znaczenie), ważność, wagę. Kynbípb symbolizuje: magię, czary, właściwości nadprzyrodzone (percepcja świata; wierzenia, zaklęcia), wrogość 
do człowieka, wysiłek, trud zrywania, poświęcenie, wyrzeczenie (percepcja świata); Kupalnicę (obrzęd ludowy). Archetyp symbolu (metaforycznego) trybuli jest ludowy.

Obraz trybuli w idiostylu Jesienina. Kynb́pp postrzegany był przez Jesienina jako roślina związana z magią, czarami. Dostrzegał również jej walory smakowe. Uwagę poety zwróciły delikatne, miękkie, pokryte puszkiem liście trybuli, co stało się podstawą porównania do wygodnego posłania.

Uwagi końcowe. Podsumowując należy stwierdzić, że w twórczości poetyckiej Jesienina zioła odegrały kluczowe znaczenie przede wszystkim w początkowym okresie twórczości, związanym z pobytem w rodzinnej wsi Konstantinowo, położonej nad rzeką Oką. Opis symboliki roślin zielnych związany jest z wieloma wierzeniami i obrzędami ludowymi, np. zrywanie roślin podczas Kupalnicy, uczestnictwo w korowodach. Ciekawa jest symbolika ziół wynikająca z aspektów kulturologicznych (терем темный). Nierzadko poeta wzoruje się na ustnych pieśniach ludowych, legendach itp., stąd np. przedmioty nieożywione posiadają cechy istot żywych. Analiza symboliki roślin zielarskich wykazała, że często kojarzone są z miejscem dzieciństwa i wczesnej młodości, stając się ich symbolami (сторона ковыльной пущчи, В том краю, где желтая крапива). Do opisu poetyckiego roślin Jesienin wykorzystuje leksykę gwarową, używa nazw zwyczajowych roślin (прутник, ветла). Można zauważyć, że postrzeganie roślin, ich symbolika zależy m.in. od zjawisk społeczno-politycznych (рдяный мак заката), pory roku i dnia (высохший ковыль, заросшая крапива / Обрядилась ярким перламутром), nastroju podmiotu lirycznego (Маком влюбленное сердие иветет).

Jesienin z łatwością łączy magię, wzniosłość natury z rzeczami pospolitymi, powszedniością (opis budzącego się świtu widziany oczami pokrzywy dziewczyny). Należy stwierdzić, że specyfika symboliki ziół w utworach poetyckich Jesienina wiąże się z niezwykłą plastycznością, barwnością przedstawionych obrazów poetyckich, co pozwala zobaczyć barwy natury, usłyszeć jej dźwięki, niekiedy poczuć jej zapach i obdarzyć ją określonym uczuciem. 


\section{Bibliografia}

1. Kop - Kopaliński W. Słownik symboli. Warszawa: Wiedza Powszechna, 1991. 509 s.

2. Markiewicz H. Uwagi o semantyce i budowie metafory // Studia o metaforze II. Z dziejów form artystycznych $w$ literaturze polskiej / Pod red. Głowińskiego M. i Okopień-Sławińskiej A. Wrocław: Ossolineum. PAN, 1983. S. 43- 59.

3. Mała Encyklopedia Powszechna PWN / Pod red. H. Boneckiego. Warszawa: PWN, 1974. 945 s.

4. Ogrodowska B. Zwyczaje, obrzędy i tradycje w Polsce. Warszawa: Verbinum Wydawnictwo Księży Werbistów, 2001. 309 s.

5. Ricoeur P. Egzystencja i hermeneutyka. Rozprawy o metodzie. Warszawa: PIW, 1985. 383 s.

6. Węsierski M. Humanistyka naukowa a filozoficzne koncepcje symbolu. Rozważania metasemiotyczne. // Studia semiotyczne. 2004. T. 25. Warszawa: Polskie Towarzystwo Semiotyczne. ZnakJęzyk-Rzeczywistość. S. 323-336.

7. БАС - Чернышев В.И. Словарь современного русского литературного языка: в 17 т. Москва Ленинград: Изд-во АН СССР, 1950-1965.

8. Е - Есенин С.А. Собрание сочинений: в 3 т. М.: Изд-во Правда, 1977. 447 с.

9. О - Ожегов С.И. Словарь русского языка. М.: Рус. яз., 1981. 816 с.

10. САР - Словарь Академии Российской 1789-1794. Т. I-VI. М.: МГИ им. Е. Р. Дашковой, 2001-2006.

11. СД - Толстой Н. И. Славянские древности. Этнолингвистический словарь: в 5 т. М.: Международные отношения, 1995-2012.

12. СРНГ - Словарь русских народных говоров. Т. І . М.: Наука, 1965.

13. Шелестюк Е. В. О лингвистическом исследовании символа // Вопросы языкознания, 1997. Ч. 4. С. $125-143$.

\section{References}

1. Kop - Kopaliński W. Słownik symboli. Warszawa: Wiedza Powszechna, 1991. 509 s.

2. Markiewicz H. Uwagi o semantyce i budowie metafory // Studia o metaforze II. Z dziejów form artystycznych w literaturze polskiej / Pod red. Głowińskiego M. i Okopień-Sławińskiej A. Wrocław: Ossolineum. PAN, 1983. S. 43- 59.

3. Mała Encyklopedia Powszechna PWN / Pod red. H. Boneckiego. Warszawa: PWN, 1974. 945 s.

4. Ogrodowska B. Zwyczaje, obrzędy i tradycje w Polsce. Warszawa: Verbinum Wydawnictwo Księży Werbistów, 2001. 309 s.

5. Ricoeur P. Egzystencja i hermeneutyka. Rozprawy o metodzie. Warszawa: PIW, 1985. 383 s.

6. Węsierski M. Humanistyka naukowa a filozoficzne koncepcje symbolu. Rozważania metasemiotyczne. // Studia semiotyczne. 2004. T. 25. Warszawa: Polskie Towarzystwo Semiotyczne. ZnakJęzyk-Rzeczywistość. S. 323-336.

7. BAS - Chernyshev V.I. Slovar' sovremennogo russkogo literaturnogo yazyka: v 17 t. Moskva Leningrad: Izd-vo AN SSSR, 1950-1965. 
8. E - Esenin S.A. Sobranie sochineniy: v 3 t. M.: Izd-vo Pravda, 1977. 447 p.

9. O - Ozhegov S.I. Slovar' russkogo yazyka. M.: Rus. yaz., 1981. 816 p.

10. CAP - Clovar' Akademii Rossiyskoy 1789-1794. T. I-VI. M.: MGI im. E. R. Dashkovoy, 20012006.

11. SD - Tolstoy N. I. Slavyanskie drevnosti. Etnolingvisticheskiy slovar': v 5 t. M.: Mezhdunarodnye otnosheniya, 1995-2012.

12. SRNG - Slovar' russkikh narodnykh govorov. T. I . M.: Nauka, 1965.

13. Shelestyuk E. V. O lingvisticheskom issledovanii simvola // Voprosy yazykoznaniya, 1997. Ch. 4. P. 125-143.

\section{Йоланта Кур-Кононович \\ ПРО СИМВОЛІКУ ЦІЛЮЩИХ ТРАВ В ІДІОСТИЛІ СЕРГІЯ ЄСЕНІНА}

Мета статті - лінгвістичний аналіз символіки цілющих трав в ідіостилі Сергія Єсеніна. Матеріал для аналізу - фрагменти поетичних творів поета. Метод семантичного аналізу в статті поєднується 3 методом лінгвокультурологічного опису мовного матеріалу в функціональносемантичних полях. Цілющі трави репрезентують субполе „рослини” у функціонально-семантичному полі „природа”. Предметом аналізу стали назви ковыль, купырь, крапива, мак. У статті обговорюється питання архетипів символів. Опису піддаються стилістичні мовні засоби, що допомагають зобразити окремі символи цілющих трав в ідіостилі Єсеніна. Виділено, між іншим, символи: метафоричні, метонімічні, порівняння тощо. Аналіз показав специфіку і винятковість символіки цілющих трав у поетичних творах Єсеніна, що є наслідком надзвичайної закоханості поета у природу.

Ключові слова: поезія, семантика, символіка, идіостиль, метафорика.

J. Kur-Kononowicz (https://orcid.org/0000-0001-9107-4790),

Doctor of Philology (PhD),

Associate Professor in Institute of Russian Studies of Rzeszów University,

2B Rejtana str., 35-315 Rzeszów, Poland,

tel.: +48(17)8721220,

jolanta_malgorzata@wp.pl

\section{REFLECTIONS ON SYMBOLISM OF HERBS \\ IN THE IDIOSTYLE OF SERGEI YESENIN}

\section{Summary}

The aim of the article is a linguistic analysis of the symbolism of herbs in the idiostyle of Sergei Yesenin. The research material is the original poems by the Russian poet. The method of the semantic analysis in the article is combined with the linguistic and cultural method of linguistic material description in semantic fields. Herbs are understood as subpoles of ,plants” in the semantic field of the meaning ,nature”. The subject of the description covers such words as: stipa (ковыль), chervil (купьрь), nettle (крапива), рорру (мак) and others. The article discusses the problem of archetypes of symbols. Stylistic language means of illustrating individual symbols of herbs in Yesenin's idiostyle are described. Among other symbols distinguished in the research are metaphorical, metonymical, those of comparison, etc. The analysis showed the specificity and uniqueness of the symbolism of herbs in Yesenin's poetic works, resulting, inter alia, from the poet's great fascination with nature.

Key words: poetry, semantics, symbolism, idiostyle, metaphor. 